\title{
Determinants of Training and Development Practices in SMEs: A Case of Japanese Manufacturing Firms
}

\author{
Aruna Gamage \\ Department of Human Resource Management \\ University of Sri Jayewardenepura \\ E-mail: gamage@sjp.ac.lk \\ And \\ Yuri Sadoi \\ Graduate School of Economics, Meijo University, Japan \\ E-mail: $\underline{\text { sadoi@ccmfs.meijo-u.ac.jp }}$
}

\begin{abstract}
Small and Medium-sized Enterprises (SMEs) constitute a large proportion of the overall business population of industrially developed and developing nations. Despite the growing importance of SME research during the last decade, very little attention has been paid to the study of training and development practices in SMEs. This article sets out to redress this imbalance in current SME research. It outlines the preliminary results of a recent study that focused on determinants of training \& development practices in manufacturing SMEs in Japan. The results of the analysis indicate that the attitude of owner/manager and organizational support towards training \& development are the key determinants of training intensity in SMEs in Japan.
\end{abstract}

Keywords: Human Resource Development, SMEs in Japan, Training \& Development Practices

\section{Introduction}

Small and Medium Enterprises (SMEs) have been playing a major role in every area of the national economy in Japan. Their importance is indicated by the very large share of the economy that they occupy. In 2001 SMEs numbered 4.7 million, and accounted for 99.7\% of all firms (excluding the primary sector). It employed 30 million persons corresponding to $70.2 \%$ of total employment. It accounted for $51.2 \%$ of manufacturing shipment volume, $64.4 \%$ of wholesale sales and $72.1 \%$ of retail sales in 2001 (METI, 2006). However, the firm exit rate in Japan has trended upward in recent years, and rose by a record annual average of $6.1 \%$ (based on the number of enterprises) between 2001 and 2004. As a consequence, the exit rate has considerably exceeded the entry rate despite the slight upward swing in the entry rate, and the gap has widened further to $2.2 \%$ in terms of number of establishments and $2.6 \%$ in terms of number of enterprises. This is the largest gap on record since statistics were first compiled in 1947 (METI, 2006). 
Successful business management of SMEs largely depends on the quality of human resource that supports companies (JASMEC, 2001). Securing and training high-quality personnel are therefore key factors for the growth of SMEs, which often have limited opportunities to utilize managerial resources. These needs for training were clearly recognized in Japan for the first time in 1960s when the country was entering a period of high economic growth (OECD, 2002). "... the balance of evidence indicates that formal training and development cuts failure rates by half- all other things being equal" (SFEDI, 1999) and "... failure rates could fall from one in three in the first three years to one in ten where training was undertaken" (Story, 1994).

However, it is disheartening to note that scant attention in the SME research is given to the study of human resource management practices (HRM), particularly training provisions for workforce development. The lack of research in HRM in SMEs has resulted in lack of information about human resource in SMEs which is essential for theory, research, and practice. Current human resource theory has been developed and tested in large organizations. As a result, little is known about the extent to which the theory extends to smaller entrepreneurial organizations.

Despite the growing importance of SME research during the last decade, little attention has been paid to the study of training and development practices in small and mediumsized businesses. Not only do SMEs themselves pay less attention to training, but the issue of training and development in SMEs has also been relatively neglected by academics (Pettigrew et al., 1990). Cosh, Duncan, and Hughes (1998), Marshall et al (1993, 1995), and Westhead and Storey (1997) have attempted to rectify this situation. However, their studies are inconclusive and their focus is strictly limited to Western society. Most of these studies have used a binary indicator as their measure of training (e.g. Westhead and Story 1997; Cosh et al. 1998)- whether training is provided or notbut this fails to distinguish adequately the quantity or quality of such training (Kitching $\&$ Blackburn, 2002). The recent attempt by Cosh et al. (2000) to provide a more sensitive measure of the quantity or quality of training uses training costs as a percentage of total sales. This measure, however, seems most appropriate to training which has a measurable money cost as in the case of external courses. Training which does not incur a direct or easily measurable money cost, such as that provided in-house by employers or other members of the workforce would not appear in this type of calculation. In deed, informal learning at the work place, despite its pervasiveness, may be impossible to cost because of its diffuse character. Unfortunately, this is a serious omission because small business owners often rely heavily on in-house training (Kitching \& Blackburn, 2002).

Therefore, the broad objective of this study is to extend the emerging empirical literature on the training and development practices in SMEs. Specifically, this study is designed to investigate those factors which influence the intensity of training \& development practices in manufacturing SMEs in Japan. Potential explanatory factors on training \& development include age and size of the firm, nature of control, changes in employment, organizational support and owner/ managers' attitude for training. 


\section{Literature Review}

In this section we give an overview of the main research on HRM in SMEs by which we constructed our theoretical model to be tested.

\section{Human Resource Management in SMEs}

Given the importance of SME employees to the national economy, it is disheartening to note that scant attention in the SME research is given to the study of human resource management practices. No mater where you look, in surveys (e.g., Hornsby \& Kuratko, 1990), in reviews of literature (e.g., Good, 1998), and in empirical studies (Heneman \& Berkley, 1999), scholars are lamenting over the dearth of information about human resource management practices in SMEs.

Proper management of a company's human resources is the key to business survival in today's world. The organizational effectiveness of the firm (Huselid, 1995; Terpstra and Rozell, 1993) and its ability to create a sustainable competitive advantage (Prahalad, 1983; Pfeffer, 1994) can hinge on whether HRM practices are properly thought out and successfully implemented. The human potentials in a company are generally much more difficult for competitors to duplicate than the plant, equipment or even products that a company produces (Flanagan and Despanade, 1996). Consequently, the nature and well being of a company's employees can become its main strength in carving out a profitable existence in the industry.

HRM practices can be particularly important for small firms (Marlow and Patton, 1993) since they tend to be so dependent on human capital. Research indicates that inadequate and insufficient management of employees in small firms has resulted in low productivity and high turn over rates (Mathis and Jackson, 1991) and is one of the leading causes of small business failures (McEvoy, 1984).

HRM is generally associated with large organizations. 'There is a strong relationship between size and the extent to which establishments had introduced personnel policies, procedures and other arrangement' (Price, 1994). The issue of size raises the question of the relevance of 'mainstream' HRM practices for enterprises who count their employees in tens rather than in thousands. Although no clearly articulated HRM framework exists for small and medium-sized enterprises, they like their larger counterparts also have to recruit and select staff, achieve level of performance, and train staff. Given the prevalence of small enterprises in many economies it is surprising therefore that 'relatively little is known about the extent, nature and determinants of training in small and medium-sized businesses' (Johnson \& Gubbins, 1992). Small and medium-sized enterprises are often limited in their ability to undertake HRM activities by a lack of finance, knowledge and managerial skill (Gilbert \& Jones, 2000). As a consequence, their HRM practices are highly informal and relatively unsophisticated (Jameson, 2000; Gilbert \& Jones, 2000).

The lack of information about human resource in SMEs is problematic for theory, research, and practice. Current human resource theory is often developed and tested in 
large organizations. As a result, little is known about the extent to which the theory extends to smaller entrepreneurial organizations.

\section{Training and Development Practices in SMEs}

An educated and well-trained work force is considered to be essential to the maintenance of a business firm's competitive advantage in a global economy. It is also believed that training can and should be powerful agent to facilitate a firm's expansion and the development of capabilities, thus enhancing profitability (Cosh, Duncan, and Hughes, 1998). However, Westhead and Storey (1997) suggest that employees in small and medium-sized enterprises (SMEs) are much less likely to receive training than their counterparts in larger organizations.

Much of research has, however, been rather narrow in its focus. Studies have often limited themselves to formal training (Westhead and Story, 1997; Cosh et al., 1998; Patton et al., 2000), thereby ignoring informal types of training. Recent studies show that many small employers rely heavily on in-house, on-the-job training (Vickerstaff, 1992; Johnson and Gubbins, 1992; Curren et al., 1993, 1996). Other studies have confined their scope to particular occupational groups, particularly managers (or aspiring managers), neglecting the training experiences of other categories of worker (Storey and Westhead, 1996; Loan-Clark et al., 1999; Patton et. al., 2000). Other researchers have conducted evaluations of particular training initiatives which through often insightful may not be typical of most small business (Cushion, 1995; Marshall et al., 1995; Westhead, 1997). It is questionable, whether the findings of these studies ought to be generalized to the broader small business population. These restrictions on the scope of studies may limit our understanding of the motives for, process of, and consequences of training provisions for small employers and their workforce (Kitching \& Blackburn, 2002).

The recent attempt by Cosh et al., (2000) to provide a more sensitive measure of the quantity or quality training uses training costs as a percentage of total sales. This measure, however, seems most appropriate to training which has a measurable money costs as in the case of external courses. Training which do not incur a direct or easily measurable money cost, such as that provided in-house by employers or other members of the workforce would not appear in this type of calculation. In deed, informal learning at the work place, despite its pervasiveness, may be impossible to cost because of its diffuse character. Unfortunately, this is a serious omission because small business owners often rely heavily on in-house training (Kitching \& Blackburn, 2002).

Therefore, to rectify this situation an attempt was made to identify factors which influence the intensity of training \& development and their relative importance in SMEs in Japan.

\section{Factors Influencing Training \& Development Intensity in SMEs}

Training \& development (the 'dependent variable') refers to any activities at all through which managers and workers improve their work-related skills and knowledge. These activities may occur in short burst or be over a longer period of time. They may be linked to a qualification or not (Kitching \& Blackburn, 2002). In order to examine different aspects of training \& development activities in SMEs, a cumulative training intensity 
index which consists of eight training \& development related variables; formal and informal training, team based work, job rotation, educational assistance, performance based pay, quality circles, TQM practices, and learning by doing, was calculated.

Here, it is examined those factors which influence the intensity of training \& development practices in manufacturing SMEs. Potential explanatory factors fall into two broad categories- background variables and organizational variables. Background factors include; age and size of the firm, nature of control, change in employment, and business sector. Organizational factors consist of two variables; organizational support for training $\&$ development and attitude of owner/manager for training provision.

\section{Conceptual Framework and Hypotheses}

Having combined elements from different theoretical perspectives on Human Resource Development; the resource-based perspective, the human capital theory and institutional approach, a framework on training and development in SMEs can be constructed.

The framework is used to derive six hypotheses on the application of training provisions within SMEs. These hypotheses identify various background and organizational variables as determinants of training intensity (see Figure 1).

\section{Age of the firm}

Age of the firm (AGE) is said to be an influential factor for training \& development intensity of a business firm. Research findings reveal that young firms tend to invest more in training and development than their older counter parts. Having examined one thousand five (1005) small firms in Britain, Kitching and Blackburn (2002) concluded that higher training index scores are associated with larger and younger firms... as well as those in the business and professional services sector.

So, our first hypothesis can be stated as follows;

\section{H1: The age of the business is positively related with the training \& development intensity of SMEs.}

\section{Firm size}

The most consistent finding in SME research is that the larger the organization (SIZE), the more likely it is to engage in training (Cambridge Small Business Research Center, 1992; Marshall et al., 1995). Large firms may benefit from scale effects in the usage of training practices, even when training unit or manager is absent. This suggests that firm size also has a direct effect on the usage of training practices.

Furthermore, most training practices require considerable development costs (Klaas et al., 2000). This results in a cost advantage for larger firms, which is strengthened by the limited supply of financial resources of many small firms. Consequently, larger firms would benefit more from departments and/or employees that have specific knowledge and expertise on the implementation of such training practices. Larger firms are, therefore, more likely to have a separate training unit or person responsible for training than smaller ones. This relationship is confirmed by previous studies (Hornsby and 


\section{Figure: 1 Determinants of Training \& Development Intensity}

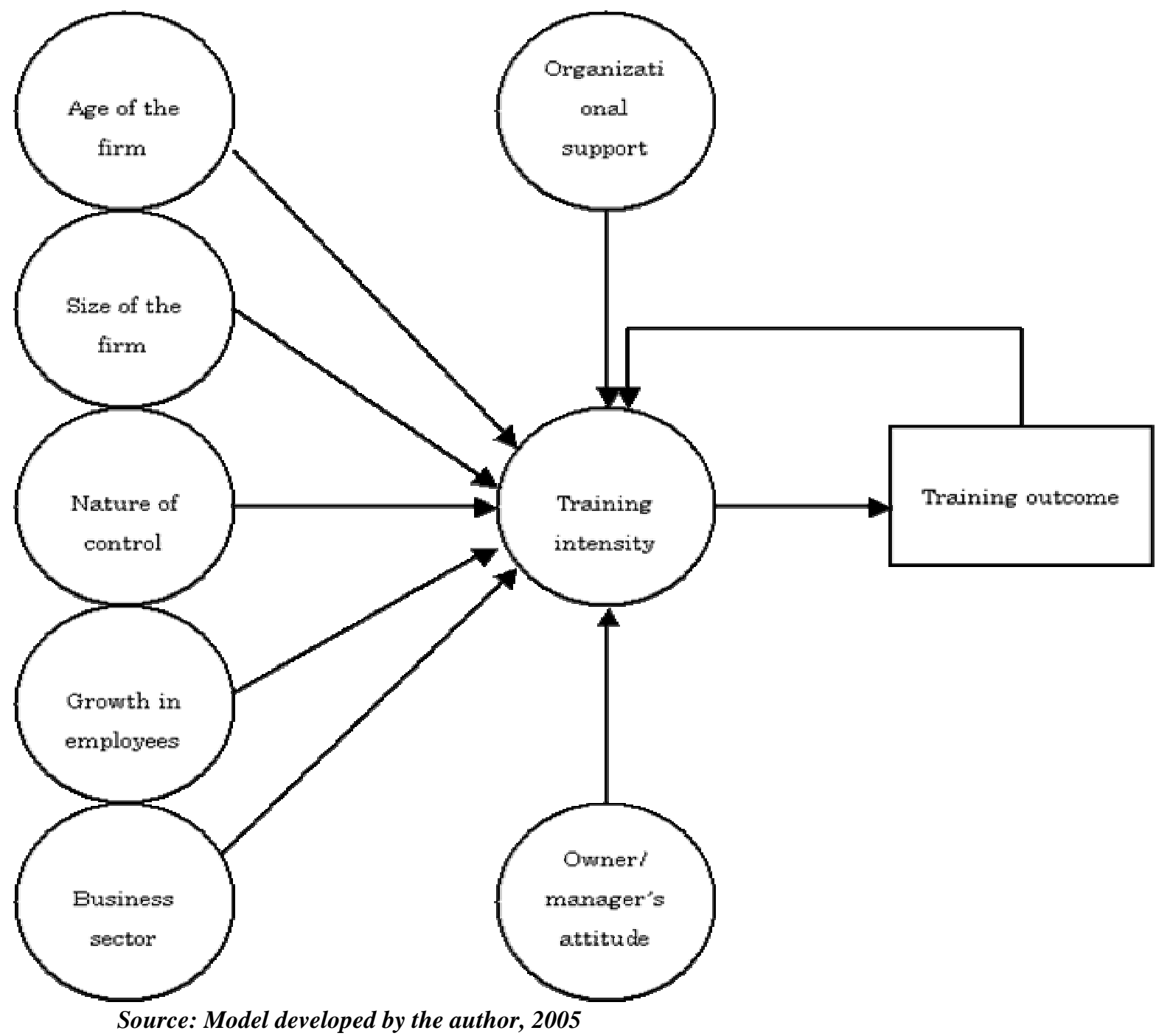

Kuratko, 1990). In turn, the presence of such a department or manager will have a positive impact on the application of training practices.

To conclude, it is hypothesized the existence of a direct effect of firm size on the usage of training \& development practices. So, the second hypothesis can be stated as follows:

H2: Firm size is positively related with the intensity of training and development practices.

\section{Nature of control}

Nature of control (CONTROL) affects the training intensity of a business. A business unit may be controlled and managed either by the owner manager or paid manager. Some argues that paid managers tend more to invest in training $\&$ development activities while others argue that the owner manager is more likely to invest more in training \& development. 
The influence of ownership has been noted by various researchers. Martin and Staines (1994) have identified that owners and partners place more emphasis on technical rather than managerial skills, whereas non-owner managers reversed the relative importance of these two factors. This may be because non-owner managers are interested in career progression. It may also be the case that owner-managers feel threatened if their subordinates develop their managerial competence. Cromie et al. (1995) have identified that family firms were less keen on formal management training than non-family firms.

Training and development is unlikely to be provided as it is feared that, it will make the manager more attractive in the labor market (Storey and Westhead, 1996). This sentiment is shared by Loan Clarke et al. (1999), who found that small firms without a family member in the management team invested more time and money in management training and development. They believe that family-run organizations may feel threatened by nonfamily managers improving their competence. Similar views are held by Smith and Whittaker (1998) in relation to workforce training, where human resource development is said to be reactive rather than involving an ongoing, long-term commitment.

These arguments suggest that the perceived value for high performance work practices including training \& development may be relatively low for owner managed or owner controlled business units. This results in the following hypothesis:

H3: Firms managed by owner-manager(s) are less likely to apply training \& development practices than firms managed by paid managers.

\section{Growth in employees}

Growth in employees (GROEMPL) makes a significant influence on the application of training and development practices in a firm in several ways. First of all, if the number of employees increases, so does the need to decentralize and communicate between employees and departments. This, in turn, requires a high level of standardization, specialization and formalization (Daft, 1998; Nooteboom, 1993). In addition, an increase of the number of employees results in an increasing demand for training practices. However, Kitching \& Blackburn (2002) state that the evidence on the relationship between training provision and employment change offers a very mixed picture.

These arguments lead to our fourth hypothesis which is stated as follows:

\section{H4: Growth in employment is positively related with training \& development intensity in a business firm}

\section{Business sector}

Business sector seems to make an influence on training \& development intensity of a business unit. Some argue that firms in service sector may tend to apply more training \& development practices than in other sectors. Kitching and Blackburn (2002) argue that firms in business professional service sector apply more training \& development 
practices than in others. Wong et al. (1997) have suggested that different industrial sectors have different training requirements. In relation to management training, they propose that service sector SMEs may place greater emphasis on training management to maintain customer relationships. However, as this study is confined only to SMEs in manufacturing sector, analyzing the relation between the 'sector' and 'training intensity' is beyond the scope of this study.

\section{Organizational support}

Organizational support (ORGSUPT) for training is said to be an influential factor for training intensity. This can be measured as a cumulative index which takes into account the presence or absence of a separate unit or person responsible for training, training plan, budget for training, training policies, and training manuals, hand books etc. If the firm does not provide support for or undertake a commitment to employee training, a firm may focus little attention on training activities. We may thus expect a strong correlation to exist between the degree of organizational support for training and training intensity. Hence, we hypothesis:

\section{H5: Firms with a strong organizational support tend to apply more training and development practices}

\section{Attitude of the owner/ manager}

The importance of owner/ manager attitudes (ATTITUD) towards training in small business has been discussed extensively elsewhere (Matlay, 1997, 1998, 1999). Magjuka (1988) concludes that managerial beliefs are strongly and positively associated with the pattern and frequency of training in a firm. The influence of the owner-manager is a key feature impacting upon training and development in the small firm. Ross (1993) and Kerr and McDougall (1999) maintain that the propensity or motivation to engage in HRD is dependent on the attitude of the senior manager(s), as they determine the ethos and strategic direction for the organization. Research indicates that in the majority of firms employing less than 50 people, the owner-manager takes sole responsibility for the management of human resources (Hornsby and Kuratko, 1990; MacMahon and Murphy, 1999). The implications of this are that effective HRM (and HRD) depends on the skills, attitudes and experience of one individual (MacMahon and Murphy, 1999). The ownermanager therefore exerts a considerable influence on the likelihood and nature of small firm HRD (Hill and Stewart, 2000). These arguments lead to our sixth hypothesis which is stated as follows:

\section{H6: Attitude of the owner/ manager has a positive impact upon the intensity of Training in SMEs}

All the above hypothetical relationships can be summarized as in Table 1. 
Sri Lankan Journal of Human Resource Management

Table: 1 Variables affecting training intensity in SMEs: hypothesized relationship

\begin{tabular}{|c|c|c|c|}
\hline Variable & Definition/description & $\begin{array}{l}\text { Hypothesized } \\
\text { relationship }\end{array}$ & $\begin{array}{l}\text { Non-parametric statistical test } \\
\text { used in the analysis }\end{array}$ \\
\hline \multicolumn{4}{|c|}{ Background variables } \\
\hline AGE & Age of the business & + & Mann-Whitney U test \\
\hline SIZE & Size of the business & + & Spearman Rank correlation \\
\hline CONTROL & Managed by owner & - & Mann-Whitney U test \\
\hline GROEMPL & Growth in employment & + & Mann-Whitney U test \\
\hline \multicolumn{4}{|c|}{ Organizational variables } \\
\hline ORGSUPT & Organizational support & + & Spearman Rank correlation \\
\hline ATTITUD & Attitude of the owner & + & Spearman Rank correlation \\
\hline
\end{tabular}

Source: Developed by the author, 2005

\section{Sample and Procedure}

\section{Method}

The organizations included in this research were selected from a random sample of 326 Manufacturing SMEs in Nagoya, Aichi Prefecture in Japan. Nagoya is the fourth largest city in terms of the industrial contribution to GDP and plays a crucial role in the economic development in Japan. A list of Manufacturing SMEs whose employees are less than 300 but more than 10 was compiled from the Nagoya Chamber of Commerce. Enterprises whose employees are more than 300 were not included in the sample because they are considered to be large enterprises according to the defining of SMEs in Japan. Enterprises whose total employees are less than 10 were not included as they do not have a formal unit dealing with HRM.

There were 2691 manufacturing SMEs in Nagoya in the mid 2003 whose total employees are in between 10-300. Out of this, there were 71 enterprises that have been registered out side Nagoya city. So it was deducted from the total population, as it does not fall within the population frame. On the other hand, there were 328 enterprises that were carrying out their operations outside Nagoya city limit but have been registered in Nagoya. So, these enterprises were included in our total population resulting 2948 enterprises as our total population. From this a sample of 326 was selected randomly.

A self administered questionnaire was sent to the owner/manager of 326 organizations at the end of the 2003 fiscal year. The questionnaires were sent to owner/ manager for two main reasons. First and foremost, they have the greatest access to the data related to training activities. Second, they have the largest storehouse of knowledge about the overall activities of the organization at the macro level, as opposed to the narrow departmental level. Nevertheless there is a fear that respondents who have direct responsibility for the implementation of training \& development activities will make a subjective evaluation. In an attempt to minimize the respondents' subjectivity as much as possible, most of our questions dealt only with raw data regarding training \& development practices. 
An extensive telephone follow up was made two weeks after the questionnaires were sent. A total of 120 firms participated in this survey resulting 37 percent response rate. However, due to the incompletion of data, fifteen (15) questionnaires have to be abandoned. So, the remaining 105 firms considered as the usable response rate which is 32 percent. This rate can be considered as "considerably high response rate" due to the inherent nature of low response rate in mail questionnaire survey.

\section{Measures}

The dependent variable, training \& development intensity (TRAINING) was measured by using a cumulative index comprising eight measures; formal and informal training, team based work, job rotation, educational assistance, performance based pay, quality circles, TQM practices, learning by doing. The reliability of TRAINING measure was evaluated and found to be acceptable with a Cronbach alpha of 0.88. (All the variables and their measures are indicated in Table 2).

The empirical analysis was conducted by univariate as well as multivariate approach. First, the hypothesized relationship between training \& development and the independent variable was tested by non-parametric statistical test which makes minimal assumptions about the underlying distribution of data. The independent variables were then tested in the second level analysis with multivariate regression models to explain variation in training intensity. The regression models were all rigorously tested to avoid multi colinearity and auto correlation.

\section{Results}

The empirical results of the non-parametric tests are shown in Table 3. On the whole, all background variables except the age of the business, and all the organizational variables are related to training intensity. The result of the Mann-Whitney U test found that there was no any significant relation between the age of the business and training provisions. Although some studies (ex. Kitchen and Blackburn, 2002) had found that young firms invest more in training, this study, based on Japanese sample, has been unable to establish such a clear relationship between these two variables.

As expected, the size of the organization had a significant impact on training \& development intensity. Spearman Rank correlation identified significant relation between the size, measured by the number of employees of the SME, and training intensity both positive and significant $(\mathrm{r}=.36, \mathrm{P}<0.01)$.

The nature of control had a big impact on investment in training. Mann-Whitney U test identified significant positive correlation between non-owner managed SMEs and training intensity $(55.8,40.5, \mathrm{p}<0.05)$.

As going far with the size, growth in employment shows positive and significant correlation with training intensity. Mann-Whitney $U$ test identified this relation both positive and significant $(63.7,49.2, \mathrm{p}<0.05)$. 
Sri Lankan Journal of Human Resource Management

Table: 2: Variables and its Measures

\begin{tabular}{|c|c|c|}
\hline Variable & Variable name & Measure \\
\hline \multicolumn{3}{|l|}{ Dependent variable } \\
\hline Training \& development & TRAINING & $\begin{array}{l}8 \text { items concerning training \& } \\
\text { development practices }\end{array}$ \\
\hline \multicolumn{3}{|l|}{ Independent variables } \\
\hline \multicolumn{3}{|l|}{ Background variables } \\
\hline Age of the firm & AGE & $\begin{array}{l}1=\text { More than } 20 \text { years } \\
0=\text { Less than } 20 \text { years }\end{array}$ \\
\hline Size of the firm & SIZE & Log of total employees \\
\hline Nature of control & CONTROL & $\begin{array}{l}1=\text { Managed by paid managers } \\
0=\text { Managed by the owner/ partner }\end{array}$ \\
\hline Growth in employees & GROEMPL & $\begin{array}{l}1=\text { increased in last three years } \\
0=\text { not increased in last three years }\end{array}$ \\
\hline \multicolumn{3}{|l|}{ Organizational variables } \\
\hline Organizational support & ORGSUPT & $\begin{array}{l}5 \text { items relating to organizational } \\
\text { support }\end{array}$ \\
\hline $\begin{array}{l}\text { Attitude of owner/ } \\
\text { manager }\end{array}$ & ATTITUD & 4 items relating to attitudes \\
\hline
\end{tabular}

Source: Developed by the author, 2005

Table: 3 Non-parametric statistical tests of variables affecting management training

\begin{tabular}{|c|c|c|c|}
\hline Variable & Definition/ description & $\begin{array}{l}\text { Statistical } \\
\text { significance }\end{array}$ & $\begin{array}{l}\text { Empirical } \\
\text { relationship }\end{array}$ \\
\hline \multicolumn{4}{|c|}{ Background variables } \\
\hline AGE & Age of the business & ns & \\
\hline SIZE & Size of the business & $* *$ & $+(r=36)$ \\
\hline CONTROL & Non-owner managed & $*$ & $+(55.8,40.5)$ \\
\hline GROEMPL & Growth in employment & $*$ & $+(63.7,49.2)$ \\
\hline \multicolumn{4}{|c|}{ Organizational variables } \\
\hline ORGSUPT & Organizational support & ** & $+(\mathrm{r}=63)$ \\
\hline ATTITUD & Attitude of owner/manager & ** & $+(\mathrm{r}=62)$ \\
\hline
\end{tabular}

Source: Survey data, 2005

* Significant at $.05 * *$ significant at .001

As expected, organizational support for training was highly correlated with training intensity. Spearman Rank correlation coefficient identified this relation as positive and highly significant $(r=.63, \mathrm{p}<0.01)$.

Attitude of the owner/manager is also a very much influential factor in determining training intensity in a SME. It means positive attitude of the owner/ manager towards training \& development will results in high investment in training activities. Spearman Rank correlation identified this relation as both positive and significant $(r=0.62, p<0$ $.01)$. 
The correlation of these variables except age, with the training \& development intensity is positive and significant, thus providing initial support for the hypotheses.

Table 4 presents the results of the full model of the multivariate regression analysis. Regression of the study variables on TRAINING resulted in a highly significant model with an adjusted R Square of .475. However Beta weights only for SIZE, ORGSUPT and ATTITUDE were significant and in the predicted direction thus supporting Hypotheses 2 , 5 and 6 only.

Table: 4 The determinants of variations in the level of training intensity of SMEs

\begin{tabular}{lllll}
\hline Independent variable & Std. Beta & T & p-value & VIF \\
\hline Background variables: & & & & \\
AGE & 0.016 & 0.228 & .820 & 1.026 \\
SIZE & 0.161 & 2.040 & .044 & 1.236 \\
CONTROL & 0.049 & 0.642 & .522 & 1.159 \\
$\quad$ GROEMPL & 0.102 & 1.353 & .179 & 1.119 \\
Organizational Variables & & & & \\
$\quad$ ORGSUPOT & 0.247 & 3.111 & .002 & 1.249 \\
$\quad$ ATTITUDE & 0.462 & 5.503 & .000 & 1.398 \\
& & & & \\
Adjusted R Square & 0.475 & & & \\
F-statistics & 16.671 & & & \\
P-value & 0.000 & & &
\end{tabular}

Source: Survey data, 2005

\section{Discussion}

The primary purpose of this study was to explore key determinants that affect training intensity of manufacturing SMEs in Japan. Specifically, this study tried to uncover various background and organizational variables that determine the training \& development intensity in SMEs in Japan.

In the first stage of analysis (Table 3), it was found a significant positive relation between all background variables except the AGE and all the organizational variables with training \& development intensity in SMEs, thus providing initial support for our all hypotheses except the first.

In the second stage of the analysis, the model was regressed rigorously by using the standardized regression analyses. The most conspicuous result of this analysis (Table 4) was that the size of the organization, measured by the number of employees was the only variable among the background variables which was significantly correlated with training intensity. This result reconfirms the previous research finding of Ross, (1993), Kerr and McDogall (1999), Hilland Stewart (2000), MacMahon and Murphy (1999).

Furthermore, the results indicated that organizational variables, 'organizational support for training' and 'attitude of the owner/ manager were highly correlated with training 
intensity showing those as key determinants of training \& development intensity in manufacturing SMEs in Japan.

Organizational support for training, such as the presence of a separate unit or a person responsible for training, training plan, budget for training, training policies, training manuals etc. are very influential factors for training \& development intensity in SMEs. This is both positively and significantly correlated with the training intensity.

Attitude of the owner/manager towards training has the most influential power for training in SMEs. This is strongly correlated with training intensity. This gives the idea that the positive attitude of owner/manager towards training gives rise to the high takes up of training initiatives in SMEs. This finding reinforces the findings of many previous researches. Ross (1993) and Kerr and McDougall (1999) maintain that the propensity or motivation to engage in training and development is dependent on the attitude of the senior manager(s), as they determine the ethos and strategic direction for the organization. The implications of this are that effective HRM (and HRD) depends on the skills, attitudes and experience of one individual (MacMahon and Murphy, 1999). The owner-manager therefore exerts a considerable influence on the likelihood and nature of small firm HRD (Hill and Stewart, 2000).

\section{Conclusions}

This study provides an initial consideration of key determinants of training \& development practices in manufacturing SMEs in Japan. We considered the importance of range of background factors and organizational factors. Background factors included: age and size of the firm, nature of control and growth of employment. Organizational factors included organizational support for training and owner/ manager attitude.

Preliminary analysis shows that all the background variables, except the age of the business, and all the organizational variables were, more or less, related to the intensity of training \& development. However, nature of control and the growth in employees were much less important than expected. What our results do show is that the attitude of the owner/ manager towards training is the most influential factor in determining the intensity of training \& development in SMEs in Japan. Further, the results show that organizational support for training and the size of the firm are the other important determinants next to the attitude in determining the training \& development intensity in manufacturing SMEs in Japan.

\section{References}

Bacon, N., P. Ackers, J. Storey, and D. Coates (1996), It's a small world: managing human resources in small businesses, International Journal of Human Resource Management, 7, 7, 82-100.

Becker, B., and B. Gerhart (1996), The impact of human resource management on organizational performance: Progress and prospects, Academy of Management Journal, 39(4), 779-801.

CBI (1993), Finance for growth: Meeting the financial needs of small and medium enterprises, London: Confederation of British Industry. 
Cambridge Small Business Center (1992), The state of British enterprises: growth, innovation and competitive advantage in small and medium-sized firms, Cambridge: University of Cambridge.

Cosh, A., J. Duncan, and A. Hughes (1998), Investment in training and small firm growth and survival: an empirical analysis for the UK 1987-95, DfEE Publication, Research Report, No. 36, London: HMSO.

Cosh, A., A. Hughes, and M. Weeks (2000), The relationship between training and employment growth in small and medium-sized enterprises, Research Report, RR245, Department for Education and Employment, Norwich NR3 IBQ.

Cromie, S., B. Stephenson, and D. Monteith (1995), The management of family firms: an empirical investigation, International Small Business Journal, 13, 4, 11-13.

Curran, J., R. A. Blackburn, J. Kitching, and J. North (1996), Establishing small firms' training practices, needs, difficulties and use of industry training organizations, Research Studies RS17, DfEE/HMSO, London.

Curren, J., J. Kitching, B. Abbott, and V. Mills (1993), Employment and Employment Relations in the Small Service Sector Enterprises, Kingston Business School, Kingston Polytechnic.

Cushion, N. (1995), How to succeed in Small Business Training: a Breakthrough, Centre for Applied Research in Management, Education and Training, Norwich.

Daft, R. L. (1998), Essentials of Organization Theory and Design, Cincinatti, Ohio: South-Westen College Publishing.

Flangan D. S. and S. P. Despande (1996), Top management's perceptions of changes in HRM practices after union elections in small firms, Journal of Small Business Management, 34(4), 23-34.

Gamage, A (2005), Human Resource Development in SMEs in Japan, Doctoral Thesis (unpublished).

Gilbert, J. and G. Jones (2000), Managing human resources in New Zealand small business, Asia Pacific Journal of Human Resources, 38(2): 55-67.

Good, D. C. (1998), Gender and Successful Human Resource Decision in Small Business, New York, Garland publishing, Blackpool.

Henman, H. G. III, and R. A. Berkley (1999), Applicant attraction practices and outcomes among small businesses, Journal of Small Business Management, 37 (1), 53- 74 .

Hill, R., and J. Stewart (2000), Human resource development in small organisations, Journal of European Industrial Training, 24, 2/3/4, 105-17.

Honsby , J. S, and D. K. Kuratko (1990), Human resource management in small business: critical issues for the 1990s, Journal of Small Business Management, 28(July): 918.

Huselid, A. M. (1995), The impact of human resource management practices on turnover, productivity, and corporate financial performance. Academy of Management Journal, 38 (3), 635-672.

Jameson, S. (2000), Recruitment and training in small firm, Journal of European Industrial Training, 24 (1), 43-49.

Japan Small Business Research Institute (2003), White paper on small and medium enterprises in Japan, Ministry of Economy, Trade and Industry, Tokyo. 
JASMEC, (2001), Role of Japanese SMEs play/What is an SMEs? www.jasmec.go.jp/english/act2.html (Accessed on 12th January 2005).

Jonson, S and. A. Gubbins (1992), Training in small and medium-sized enterprises: Lessons from North Yorkshire, In Small Enterprise Development: Policy and Practice, ed. Caley, K., E. Chell, F. Chittendon and C. Mason, 28-42. London: Paul Chapman Publishing.

Kerr, A and M. Mcdougall (1999), The small business of developing people, International Small Business Journal, 17(2): 1489-1503.

Keep, K. and K. Mayhew (1998), The Assessment: Education, Training and Economic Reforms, Oxford Review of Economic Policy, 4(3): i-xv.

Kitching J. and R. Blackburn (2002), The nature of training and motivation to train in small firms, Research Report, RR330, Small Business Research Center, Kingston University.

Klass, B. S., J. McCClendon and T. W. Gainey (2000), Managing HR in the small and medium enterprises: The impact of professional employer organizations, Entrepreneurship: Theory and Practice, 25(1).

Loan-Clark, J., G. Boocock, A. Smith, and J. Whittaker (1999), Competence -based management development in small and medium sized enterprises: A multistakeholder analysis, International Journal of Training and Development, 4, 3, 176-195.

MacMahon, J., E. Murphy (1999), Managerial effectiveness in small enterprises: implications for HRD, Journal of European Industrial Training, 23, 1, 25-35.

Marlow, S., and D. Patton (1993), Managing the employment relationship in the small firm: Possibilities for human resource management, International Small Business Journal, 11(4), 57-64.

Marshall, J. N., N. Aldeman, C. Wong, and A. Thwaites (1995), The impact of management training and development on small and medium sized enterprises, International Small Business Journal, 13(4), 73-90.

Martin, G. and H. Staines (1994), Managerial competencies in small firms, Journal of Management Development, Vol. 13, No. 7, pp.23-34.

Mathis, R and J. Jakson (1991), Personnel/Human Resource Management, $6^{\text {th }}$ ed. St Paul, Minn: West Publishing.

Matlay, H., (1997), Training and human resource management in small businesses: a mixed methodology approach, University of Huddersfield, Huddersfield.

Matlay, H. (1998), The paradox of training in the small business sector of the British economy, Journal of Vocational Education and Training, 49, 4, 573-89.

Matlay, H. (1999), Vocational education and training in Britain: a small business perspective, Education + Training, 41, 1, 6-13.

Matlay, H. (2002), HRD strategies in small, family and non-family business: a critical perspective, University of Edinburgh, Edinburgh.

McEvoy, M. G. (1984), Small business personnel practices, Journal of Small Business Management, 22(4), 1-8.

METI, (2006), White paper on SMEs in Japan 2006, Japan Small Business Research Institute, Tokyo

Nooteboom, B. (1993), Firm size effects on transaction costs, Small Business Economics, 5. 
OECD (2002), Management Training in SMEs, www.oecd.org/pdf (Accessed on 28th November 2004).

Ogawa, E. (1994), A management theory of small business: In search of firm-specific advantages, business alliance, and orchestral management, Small Business Monograph Series, No. 1, Osaka University of Economics.

Patton, D., S. Marlow, and P. Hannon (2000), The relationship between training and small firm performance: research framework and lost quest, International Small Business Journal, 19(1) (Oct-Dec): 2 pp11-27.

Pettigrew, A. M., M. B. Arthur and C. Hendry (1990), Training and human resource management in small and medium-sized enterprises: A critical review of the literature and a model for future research, Research and Development, No. 56, Sheffield: Training Agency.

Pfeffer, J. (1994), Competitive advantage through people: unleashing the power of the workforce, Harvard Business School press, Boston.

Prahalad, C.K. (1983), Developing strategic capability: An agenda for top management, Human Resource Management, 22(3), 237-254.

Price, L. (1994), Poor personnel practices in the hotel and catering industry: does it matter? Human Resource Management Journal, 4 (4), 44-62.

Ross, K. (1993), Training and evaluation in SMEs: manufacturing enterprises in the West Midlands, Local Economy, 8, 2, 143-54.

SFEDI (1999), Small Firms Training Impact Assessment, Executive Summary, SFEDI Center for Enterprise.

Smith, A., J. Whittaker (1998), Management development in SMEs: what needs to be done? Journal of Small Business and Enterprise Development, 5, 2, 176-85.

Story, D. J. (1994), Understanding the Small Business Sector, London: Routledge.

Story, D. and Westhead, P. (1996), Management training and small firm performance: Why is the link so weak? International Small Business Journal, 14(4)(July- Sept): 13-25.

Terpstra, E. D., and J. E. Rozell (1993), The relationship of staffing practices to organizational level measures of performance, Personnel Psychology, 46 (1), 2748.

Vickerstaff, S. (1992), The training needs of small firms, Human Resource Management Journal, 7, 2, 61-71.

Westhead, P. (1997), Factors associated with the provision of job-related formal training by employers, International Journal of Entrepreneurial Behavior and Research, 4, 3, 187-216.

Westhead, P. and D. Story (1997), Training Provision and development of small and medium-sized enterprises, DFEE Publications.

Wong, C., Marshall, J. N., Alderman, N. and Thwaites, A. (1997), Management training in small and medium-sized enterprises: methodological and conceptual issues, The International Journal of Human Resource Management, Vol. 8 No. 1, pp. 4465. 